\title{
Alkaline extraction of seaweed carrageenan hydrocolloids using cocoa pod husk ash
}

Rhein-Knudsen, Nanna; Ale, Marcel Tutor; Rasmussen, Søren; Kamp, Simon Kjær; Bentil, Joseph A.; Meyer, Anne S.

Published in:

Biomass Conversion and Biorefinery

Link to article, DOI:

10.1007/s13399-018-0305-y

Publication date:

2018

Document Version

Peer reviewed version

Link back to DTU Orbit

Citation (APA):

Rhein-Knudsen, N., Ale, M. T., Rasmussen, S., Kamp, S. K., Bentil, J. A., \& Meyer, A. S. (2018). Alkaline extraction of seaweed carrageenan hydrocolloids using cocoa pod husk ash. Biomass Conversion and Biorefinery, 8(3), 577-583. https://doi.org/10.1007/s13399-018-0305-y

\section{General rights}

Copyright and moral rights for the publications made accessible in the public portal are retained by the authors and/or other copyright owners and it is a condition of accessing publications that users recognise and abide by the legal requirements associated with these rights.

- Users may download and print one copy of any publication from the public portal for the purpose of private study or research.

- You may not further distribute the material or use it for any profit-making activity or commercial gain

- You may freely distribute the URL identifying the publication in the public portal 


\title{
Alkaline extraction of seaweed carrageenan hydrocolloids using cocoa pod husk ash
}

\author{
Nanna Rhein-Knudsen ${ }^{1} \cdot$ Marcel Tutor Ale $^{1} \cdot$ Søren Rasmussen $^{1} \cdot$ Simon Kjær Kamp ${ }^{1} \cdot$ Joseph A. Bentil $^{1}$ • \\ Anne S. Meyer ${ }^{1}$ (iD
}

Received: 25 December 2017 / Accepted: 13 February 2018

(C) Springer-Verlag GmbH Germany, part of Springer Nature 2018

\begin{abstract}
The cocoa industry in Ghana is the second largest in the world, and it generates huge amounts of cocoa pod husks, which currently represent a disposal problem as no significant use has been found for them. The husks are rich in potassium, which may be used for alkaline hydrocolloid extraction from red seaweeds. Chemical and rheological properties of K-carrageenan from Kappaphycus alvarezii and the Ghanaian red seaweed Hypnea musciformis extracted by $\mathrm{KOH}$ (benchmark) or by a cocoa pod husk ash solution were compared. Similar extraction yields and successful modification of the seaweed hydrocolloids with 3,6anhydro-galactopyranose and sulfate contents of 37-38 and 16-17\%, respectively, were obtained with cocoa pod husk ash and $\mathrm{KOH}$ extraction. Gel strengths of the K-carrageenans were also similar: $\mathrm{G}^{\prime}$ at $25^{\circ} \mathrm{C}$ were $5780 \mathrm{~Pa}$ with cocoa pod husk ash and $5930 \mathrm{~Pa}$ with $\mathrm{KOH}$. These findings have implications for industrial waste biomass utilization and sustainable green growth development of seaweed hydrocolloid processing in Ghana.
\end{abstract}

Keywords Potassium $\cdot$ Carrageenan $\cdot$ Hypnea $\cdot$ Rheology $\cdot$ Circular economy

\section{Introduction}

Ghana is the world's second largest cocoa producer after Ivory Coast, producing around 900,000 $\mathrm{t}$ of cocoa beans annually [1]. The production of cocoa beans co-generates huge amounts of cocoa pod husks (CPHs) as leftovers that constitute more than $50 \%$ by weight of the fresh cocoa pods. Currently, only very small amounts of the CPHs are used in value-added applications as, e.g., alkalis for soap production, fertilizers, and animal feed [2-4]. In practice, CPHs thus represent a disposal problem providing a large incentive for identifying sustainable use of the residues.

$\mathrm{CPHs}$ are rich in minerals, in particular potassium, but also other compounds as calcium, sodium, and magnesium are present, which could be exploited in the production of alkaline solutions for biorefinery applications [5]. When the husks are incinerated, the minerals are converted into their oxides, which

Anne S. Meyer

am@kt.dtu.dk

1 Center for Bioprocess Engineering, Department of Chemical and Biochemical Engineering, Technical University of Denmark, Søltofts Plads 229, 2800 Kgs, Lyngby, Denmark then react with the carbon dioxide formed during combustion to form carbonates. These carbonates are water soluble and can be leached with water to create alkaline solutions [5].

Ghana has a high diversity of seaweeds, and with a growing demand for hydrocolloids in various applications, the extraction of hydrocolloids from Ghanaian seaweeds represents a unique opportunity for local business development and sustainable bioresource utilization [6]. Red seaweeds are a source of agar and carrageenan hydrocolloids. These hydrocolloids, extracted from red seaweeds, are already widely used commercially in food and pharmaceutical applications due to their unique gelling properties. The red seaweed species Hypnea musciformis are available as native species in many coastal areas of Ghana [7], and extraction yields, chemical composition, and rheological properties of $\mathrm{K}$-carrageenan extracted from $\mathrm{H}$. musciformis from Ghana are comparable with $\mathrm{K}$-carrageenan from commercially used Kappaphycus alvarezii [8].

Commercially, carrageenans are extracted by alkali treatments [9]. The hypothesis behind the present study was that cocoa pod husk ash (CPHA) could be used as a substitute for potassium alkali $(\mathrm{KOH})$ currently used for extraction of carrageenans, thereby providing a useful local utilization of this cocoa industry residue while minimizing the use and import dependency of chemicals in the production of hydrocolloids. 
The present study assesses the potential of CPHA for hydrocolloid extraction by comparing hydrocolloid extraction yields, chemical composition, and rheological properties of carrageenan from $K$. alvarezii and the Ghanaian red seaweed specie H. musciformis.

\section{Materials and methods}

\subsection{Chemicals, cocoa pod husks, and seaweed samples}

All chemicals were purchased from Sigma-Aldrich Chemical Co. (St. Louis, MO, USA) unless stated otherwise. The CPHs (from Theobroma cacao) were obtained from the Cocoa Plantation Farm at Kwame Nkrumah University of Science and Technology (KNUST), Kumasi, Ghana. The CPH material was received dried and milled (particle size $<2.5 \mathrm{~mm}$ ). The Ghanaian seaweed H. musciformis was collected at Old Ningo, Ghana, while cultivated K. alvarezii was received in dry form from NhaTrang Institute of Technology Research and Application, Vietnam, and used as benchmark for extraction yields, chemical make-up, and rheological properties.

\subsection{Preparation of alkali solution from CPHA}

Dry matter and ash contents of the CPHs were determined at 105 and $550{ }^{\circ} \mathrm{C}$, respectively, according to the procedures described by the US National Renewable Energy Laboratory (NREL) $[10,11]$. Hydrogen, nitrogen, and carbon contents of the CPHA were analyzed using a EuroVector EA3000 CHNS analyzer. The method is based on the combustion of samples at $980{ }^{\circ} \mathrm{C}$ and further quantification of $\mathrm{H}_{2} \mathrm{O}, \mathrm{N}_{2}$, and $\mathrm{CO}_{2}$ by gas chromatography with thermal conductivity detection (GCTCD).

Potassium, magnesium, sodium, calcium, and phosphorous amounts in the CPHA were determined by flame atomic absorption spectroscopy (AAS) (model VGP 210, Buck Scientific, USA) at KNUST, Ghana. The CPHA used for the AAS was prepared by weighing $1 \mathrm{~g}$ of $\mathrm{CPH}$ and placing it in a crucible in a muffle furnace at $550^{\circ} \mathrm{C}$. The CPHA was then recovered by rinsing the crucible with $10 \mathrm{ml}$ water and $10 \mathrm{ml}$ of acid aqueous reagent $(400 \mathrm{~mL}$ concentrated hydrochloric acid and $133 \mathrm{~mL} \mathrm{70 \%} \mathrm{nitric} \mathrm{acid} \mathrm{was} \mathrm{mixed} \mathrm{with} 1.2 \mathrm{~L}$ distilled water and diluted to $2 \mathrm{~L}$ with distilled water). Ash and liquids were placed in a 50-mL centrifuge flask, mixed and centrifuged for $10 \mathrm{~min}$ at $3000 \mathrm{rpm}$, and the supernatant was used for elemental analysis. The analysis was performed using the method outlined by Jones et al. (1990) and Hunter et al. (1984) $[12,13]$.

Based on the amount of potassium present in the CPHA, a CPHA solution with equimolar potassium levels as the commercially used $6 \% w / v \mathrm{KOH}$ solution was prepared by adding
$167 \mathrm{~g}$ CPHA/L Milli-Q water. The $\mathrm{pH}$ of both solutions was above $13(6 \% w / v \mathrm{KOH} \mathrm{pH} \sim 14$; CPHA $\mathrm{pH} \sim 13)$.

\subsection{Carrageenan extraction and compositional analysis}

Carrageenans were extracted by either the traditional extraction method with $\mathrm{KOH}$ or with the potassium-rich CPHA solution according to the procedure outlined by RheinKnudsen et al. (2017) [8]. Seaweed (1.5 g) was mixed with $60 \mathrm{~mL} 6 \% w / v \mathrm{KOH}$ or the CPHA solution, and reaction was carried out at $80{ }^{\circ} \mathrm{C}$ for $3 \mathrm{~h}$. The potassium solutions were removed by washing and soaking of the seaweed overnight in water. Extraction was done in $30 \mathrm{~mL}$ Milli-Q water at $99^{\circ} \mathrm{C}$ for $1.5 \mathrm{~h}$. The extracted carrageenans were mixed with diatomaceous earth (Celite, Sigma-Aldrich). Then, the slurry was pressure filtered (filter paper, PP filter cloth, Sigma-Aldrich), and the carrageenans in the permeate were precipitated in $80 \%$ isopropanol, filtrated, and the carrageenans were recovered by freeze-drying. Yields were determined by weighing. The extracted material was subjected to acid hydrolysis for determination of carbohydrate monomer composition. To avoid degradation of the acid-labile anhydro-bridges, which may be degraded into galactose or 5-hydroxy-methyl-furfural by conventional hydrolysis, the reducing acid hydrolysis procedure, described by Jol et al. (1999), was applied for determination of 3,6-anhydro-galactose contents [14]. Carbohydrate compositions were determined by high-performance anion-exchange chromatography (HPAEC-PAD) using an ICS3000 system (Dionex) equipped with a CarboPac ${ }^{\mathrm{TM}}$ PA1 column with accompanying guard column. Elution was performed using $500 \mathrm{mM} \mathrm{NaOH}$ and an isocratic flow of $0.4 \mathrm{~mL} / \mathrm{min}$. Quantification was done using 3,6-anhydro-galactose (Dextra Laboratories Ltd., UK) and galactose as sugar standards that had been reduced by the reductive acid hydrolysis. Sulfate contents were determined by turbidity analysis of the $\mathrm{HCl}(0.5 \%$ by weight of carrageenan per volume in $1 \mathrm{M} \mathrm{HCl}$,

Table 1 Elemental analysis of CPHA performed by flame atomic absorption spectroscopy and GC analysis

\begin{tabular}{ll}
\hline Element & Amount $(\%$ w/w) \\
\hline $\mathrm{K}$ & $25 \mathrm{a} \pm 0.1$ \\
$\mathrm{C}$ & $23 \mathrm{a} \pm 6.4$ \\
$\mathrm{Mg}$ & $6 \mathrm{~b} \pm 0.5$ \\
$\mathrm{Ca}$ & $5 \mathrm{~b} \pm 3.6$ \\
$\mathrm{Na}$ & $3 \mathrm{~b} \pm 0.0$ \\
$\mathrm{P}$ & $2 \mathrm{~b} \pm 0.1$ \\
Undetermined & $\sim 36$
\end{tabular}

The results represents \% weight/weight of triplicate values (except for $\mathrm{Na}$ and $\mathrm{C}$ that were measured in duplicates) [data given as means $\pm \mathrm{SD}$ ]. Different roman lowercase letters indicate significantly different values $(p<0.05)$ by one-way ANOVA 
Table 2 Overview of hydrocolloid source, carrageenan extraction solution (CPHA or $\mathrm{KOH})$, extraction yield, and hydrocolloid monomer composition [data given as means $\pm \mathrm{SD}$ ]

\begin{tabular}{llllll}
\hline Hydrocolloid source & Extraction solution & $\begin{array}{l}\text { Carrageenan extraction } \\
\text { yield }[\% w / w \text { dry material }]\end{array}$ & Hydrocolloid composition & \\
\cline { 4 - 6 } & & & $\begin{array}{l}\text { Galactose } \\
{[\% w / w \text { hydrocolloid }]}\end{array}$ & $\begin{array}{c}3,6 \text {-anhydro-galactose } \\
{[\% w / w \text { hydrocolloid }]}\end{array}$ & $\begin{array}{l}\text { Sulfate content } \\
{[\% w / w \text { hydrocolloid }]}\end{array}$ \\
\hline H. musciformis & CPHA & $19 \mathrm{a} \pm 2.7$ & $40 \mathrm{a} \pm 1.0$ & $38 \mathrm{a} \pm 1.1$ & $17 \mathrm{a} \pm 0.7$ \\
& KOH & $23 \mathrm{a} \pm 3.2$ & $38 \mathrm{a} \pm 1.6$ & $37 \mathrm{a} \pm 1.1$ & $16 \mathrm{a} \pm 1.3$ \\
K. alvarezii & $\mathrm{CPHA}$ & $23 \mathrm{a} \pm 3.3$ & $42 \mathrm{a} \pm 1.0$ & $37 \mathrm{a} \pm 1.6$ & $17 \mathrm{a} \pm 1.4$ \\
& $\mathrm{KOH}$ & $25 \mathrm{a} \pm 1.4$ & $39 \mathrm{a} \pm 1.5$ & $38 \mathrm{a} \pm 1.6$ & $16 \mathrm{a} \pm 0.5$ \\
\hline
\end{tabular}

Different roman lowercase letters columnwise indicate significantly different values $(p<0.05)$ by one-way ANOVA

${ }^{\text {a }}$ All monosaccharides values are given as dehydrated monomers

$105^{\circ} \mathrm{C}, 3 \mathrm{~h}$ ) hydrolyzed samples as described by Jackson and McCandless (1978) [15].

\subsection{Fourier transform infrared spectroscopy}

Fourier transform infrared spectroscopy (ATR-FTIR) was performed on a Nicolet iS50 FTIR spectrometer (Thermo Fischer Scientific Inc., USA) with an ATR module. The $\%$ transmittance was recorded from 2000 to $400 \mathrm{~cm}^{-1}, 32$ scans with $4 \mathrm{~cm}^{-1}$ resolution [8].

\subsection{Oscillatory rheology}

Oscillatory rheology was performed principally as described previously [8]. Briefly, $1.5 \% w / v$ carrageenan was dissolved in Milli-Q water at $80^{\circ} \mathrm{C}$ and a $2 \% w / v ~ \mathrm{KCl}$ solution was added to reach a final concentration of $1 \% w / v \mathrm{KCl}$. Following $\mathrm{KCl}$ addition, the samples were heated for an additional $20 \mathrm{~min} .3$ $\mathrm{mL}$ solutions were used for analysis. The rheological properties were assessed by small-angle oscillatory rheological measurements on a HAAKE MARS rotational rheometer (Thermo Scientific Inc., Germany) equipped with a serrated parallelplate (Reologica Instruments, $\mathrm{AB}$ ) having a diameter of $650 \mathrm{~mm}$ and with a gap of $1.0 \mathrm{~mm}$. Temperature sweeps were conducted at $0.1 \mathrm{~Hz}$ during gelation by in situ cooling (80$20{ }^{\circ} \mathrm{C}$ ) and heating $\left(20-80^{\circ} \mathrm{C}\right)$ at a rate of $1{ }^{\circ} \mathrm{C} / \mathrm{min}$. The parallel-plate was covered with silicone oil to avoid sample dehydration. The storage modulus $\left(\mathrm{G}^{\prime}\right)$, the loss modulus $(\mathrm{G}$ "), and the thermal hysteresis behavior of the gels were determined as a function of temperature [8]. $\operatorname{Tan}(\delta)$ was calculated as $\tan (\delta)=\mathrm{G}^{\prime \prime} / \mathrm{G}^{\prime}[16]$

\subsection{Statistics}

GC analysis, flame atomic absorption spectroscopy, carrageenan extractions, carbohydrate monomer compositions, and sulfate contents were performed in triplicates (except the flame atomic absorption spectroscopy for $\mathrm{Na}$ and $\mathrm{GC}$ analysis of $\mathrm{C}$ which was done in duplicate) and the data are presented as means \pm standard deviation (SD). Analyses of variances (ANOVAs) were used to determine significant differences with the Tukey-Kramer test from pooled standard deviations (JMP 13 Statistical Software, SAS). Values of $p<0.05$ were considered statistically significant.

\section{Results and discussion}

\subsection{Cocoa pod husk ash composition}

The dry matter content of $\mathrm{CPH}$ was $91 \pm 1.6 \%$ by weight and ash content was $11 \pm 1.0 \%$. GC analysis of the ash revealed incomplete combustion of carbon, still accounting for around $23 \%$ of the mass (Table 1). No hydrogen and nitrogen were detected. Flame atomic absorption spectroscopy of the CPHA confirmed high amounts of potassium, 25\% w/w, and lower

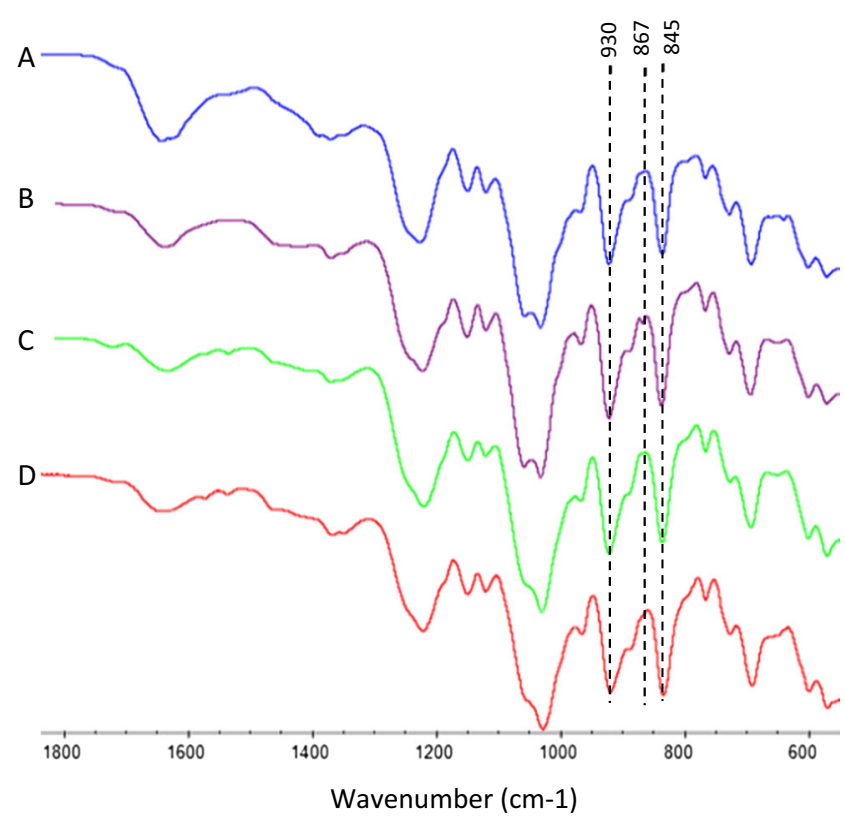

Fig. 1 FTIR analysis of carrageenans from a H. musciformis (CPHA), b H. musciformis (KOH), c K. alvarezii (CPHA), d K. alvarezii $(\mathrm{KOH})$ 


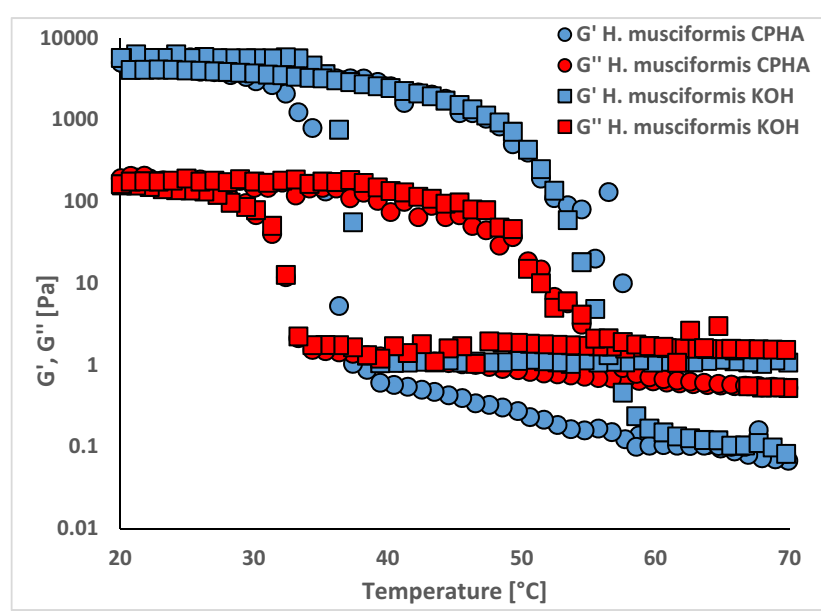

Fig. 2 Storage modulus, $\mathrm{G}^{\prime}$ [Pa] (blue) and loss modulus, $\mathrm{G}^{\prime \prime}[\mathrm{Pa}]$ (red) measured during cooling and re-heating at a rate of $1{ }^{\circ} \mathrm{C} / \mathrm{min}$ for: $1.5 \%$ carrageenan extracted from $H$. musciformis with CPHA (circles) and $\mathrm{KOH}$ (squares) with $1 \%$ added $\mathrm{KCl}$

amounts of $\mathrm{Na}, \mathrm{Ca}, \mathrm{Mg}$, and $\mathrm{P}$ (each below 6\% w/w) (Table 1). Several values (all by weight) have been reported for potassium contents, either in the form of ions or oxides: $43.5 \% \mathrm{~K}^{+}$ was reported by Simpson et al. (1985), $25.6 \% \mathrm{~K}_{2} \mathrm{O}$ was found by Yaw et al. (2015), and $37.4 \% \mathrm{~K}_{2} \mathrm{O}$ was determined by Amoanyi (2012) [17-19]. Variations in mineral contents could be a result of different factors such as soil and cultivation conditions for the cocoa plants as well as harvest time and location. Undetermined components could include silica, aluminum, and/or sulfur [18].

\section{Carrageenan extraction and characteristics}

\subsection{Extraction yield and composition}

Carrageenans were extracted from the two red seaweeds $H$. musciformis and $K$. alvarezii by either the alkaline solution produced from the CPHA or a $6 \% w / v \mathrm{KOH}$ solution. Extraction yields were highest for K. alvarezii, 23 and 25\% by weight of dry material by using CPHA and $\mathrm{KOH}$, respectively, while extraction yields for $\mathrm{H}$. musciformis were $19 \%$ by weight of dry material with the use of CPHA and $23 \%$ by weight of dry material using $\mathrm{KOH}$ (Table 2). No profound difference was observed on the extraction yields with the two different extraction techniques.

As expected, the extracted material mainly consisted of galactose, 3,6-anhydro-galactose, and sulfate, the main components of carrageenan (Table 2). The hydrocolloid compositions agree with our previously reported results [8]. Comparing the 3,6-anhydro-galactose and sulfate contents of the carrageenans extracted by either $\mathrm{CPHA}$ or $\mathrm{KOH}$ indicated a successful modification of the carrageenan precursors, as no significant difference was observed between the two constituents when comparing the two extraction solutions used (Table 2). The presence of 3,6-anhydro-galactose allows the carrageenan chains to undergo conformational changes, in turn enabling the formation of $\alpha$-helices, which are crucial for gel formation [20]. Carrageenans are heterogeneous polysaccharides composed of different dimers that define the different carrageenans, e.g., K-carrageenan is composed of dimers of Dgalactopyranose 4-sulfate and 3,6-anhydro-galactopyranose and may contain dimers from the precursor $\mu$-carrageenan, built of D-galactopyranose 4-sulfate, and D-galactopyranose 6-sulfate (and no 3,6 anhydro galactosyl residues) [21]. During the biosynthesis of carrageenans in the red seaweeds, the conversion of precursors is catalyzed by sulfurylase enzymes [22]. In industrial processing (i.e., the carrageenan extraction process), as $\mu$-carrageenan dimers are present within the $\mathrm{K}$-carrageenan chains, the cyclization reaction is catalyzed by $\mathrm{OH}^{-}$. Hence, an alkali solution, usually $\mathrm{KOH}$, is used to affect the conversion of galactopyranose into anhydrogalactopyranose and thus enhance the gelation properties of the final carrageenan product. The $\mathrm{OH}^{-}$ionizes the $\mathrm{C}-3 \mathrm{OH}$ on the sulfate galactosyl residue. The ionized form is then able
Fig. $3 \tan (\delta)$ for H. musciformis carrageenan extracted with CPHA (purple) and $\mathrm{KOH}$ (green) calculated during cooling from 80 to $20^{\circ} \mathrm{C}$ at a rate of $1{ }^{\circ} \mathrm{C} / \mathrm{min}$

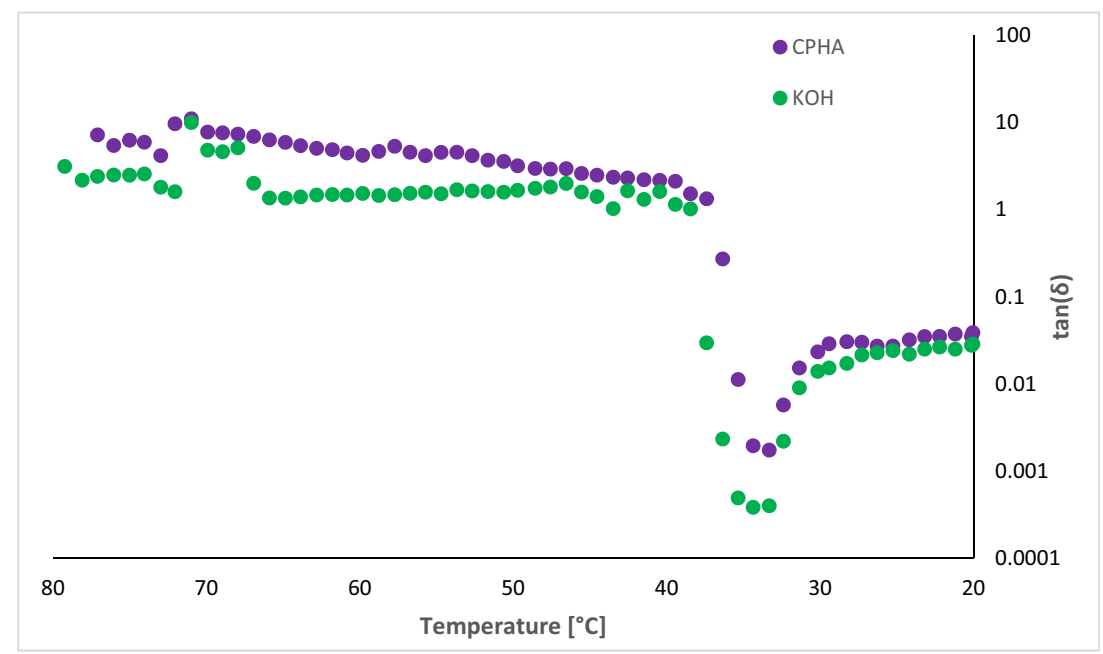


Table 3 Overview of gel strengths, gelling temperatures $\left(\mathrm{T}_{\text {gel }}\right)$, and melting temperatures $\left(\mathrm{T}_{\text {melt }}\right)$ determined by oscillatory rheology for $1.5 \%$ carrageenan with $1 \%$ added $\mathrm{KCl}$

\begin{tabular}{lllll}
\hline Hydrocolloid source & $\begin{array}{l}\text { Extraction } \\
\text { solution }\end{array}$ & $\begin{array}{l}\mathrm{Gel} \text { strength at } 25^{\circ} \mathrm{C} \\
{[\mathrm{Pa}]\left(\mathrm{G}^{\prime} \text { at } 25^{\circ} \mathrm{C}\right)}\end{array}$ & $\mathrm{T}_{\text {gel }}\left[{ }^{\circ} \mathrm{C}\right]\left(\mathrm{G}^{\prime}>\mathrm{G}^{\prime \prime}\right)$ & $\mathrm{T}_{\text {melt }}\left[{ }^{\circ} \mathrm{C}\right]\left(\mathrm{G}^{\prime}>\mathrm{G}^{\prime \prime}\right)$ \\
\hline H. musciformis & CPHA & $5779 \mathrm{~b} \pm 224$ & 36 & 58 \\
& $\mathrm{KOH}$ & $5929 \mathrm{a}, \mathrm{b} \pm 312$ & 37 & 60 \\
K. alvarezii & $\mathrm{CPHA}$ & $6584 \mathrm{a} \pm 353$ & 36 & 57 \\
& $\mathrm{KOH}$ & $5783 \mathrm{~b} \pm 7$ & 35 & 56 \\
\hline
\end{tabular}

Gel strengths at $25^{\circ} \mathrm{C}$ were determined as the averages of the three values closest to $25^{\circ} \mathrm{C} \pm \mathrm{SD}$. Different roman lowercase letters indicate significantly different values $(p<0.05)$ by one-way ANOVA to perform a nucleophilic displacement of the sulfate ester at position 6 thereby creating the anhydro-bridge. Potassium is usually used for extraction of $\mathrm{K}$-carrageenan as potassium helps increase the gel strength of the final product as it binds to the negatively sulfates thereby stabilizing the junction zones between the carrageenan helices without hindering cross-linking of the chains during gel formation [23, 24]. The data obtained affirm that the CPHA alkali solution is able to induce this modification as well (Table 2).

\subsection{Fourier transform infrared spectroscopy}

The FTIR spectra from 1800 to $600 \mathrm{~cm}^{-1}$ of the carrageenans extracted from $H$. musciformis and $K$. alvarezii with the two different alkaline solutions shown in Fig. 1 exemplify that both extractions produced $\mathrm{K}$-carrageenan moieties. The spectra show the main features of carrageenan: the moderately strong band at approximately $845 \mathrm{~cm}^{-1}$, which is assigned to $\mathrm{C}-\mathrm{O}-\mathrm{SO}_{3}$ on $\mathrm{C}_{4}$ of the D-galactopyranose 4-sulfate unit [25, 26]. The occurrence of a strong band at approximately $930 \mathrm{~cm}^{-1}$ indicates the presence of 3,6-anhydro-Dgalactopyranose and is assigned as $\mathrm{C}-\mathrm{O}$ bonds [27]. A small intensity band is observed for the $\mathrm{KOH}$-extracted carrageenan from $H$. musciformis at $867 \mathrm{~cm}^{-1}$, corresponding to the $\mathrm{C}-\mathrm{O}-$ $\mathrm{SO}_{3}$ on $\mathrm{C}_{6}$ of galactopyranose from the $\mu$-carrageenan precursor, indicating incomplete modification. No clear bands were observed at $815-820 \mathrm{~cm}^{-1}$ (also corresponding to the $\mathrm{C}$ $\mathrm{O}-\mathrm{SO}_{3}$ on $\mathrm{C}_{6}$ of galactopyranose from the $\mu$-carrageenan precursor) and at $867 \mathrm{~cm}^{-1}$ for the CPHA-extracted carrageenans [25]. The data corroborate the applicability of CPHA in the extraction and production of $\mathrm{K}$-carrageenan, as the results show that proper modification was achieved with the use of CPHA during the extraction.

\subsection{Rheological properties}

Oscillatory rheological measurements were performed to assess and compare the rheological properties of the carrageenans extracted from $H$. musciformis and $K$. alvarezii by $\mathrm{CPHA}$ and $\mathrm{KOH}$, respectively. Carrageenan with $1 \% \mathrm{w} / \mathrm{v}$ $\mathrm{KCl}$ added $(1.5 \% \mathrm{w} / \mathrm{v})$ was used for analysis, and the storage modulus, $\mathrm{G}^{\prime}[\mathrm{Pa}]$, and loss modulus, $\mathrm{G}^{\prime \prime}[\mathrm{Pa}]$, were measured over a temperature range from 80 to $20^{\circ} \mathrm{C}$. Evaluation of reversible gelling properties was done by re-heating back to $80{ }^{\circ} \mathrm{C}$. The gelling profile from 20 to $70{ }^{\circ} \mathrm{C}$ of the carrageenans extracted from $H$. musciformis are shown in Fig. 2. Initially, $\mathrm{G}^{\prime}$ is observed to be lower than $\mathrm{G}^{\prime \prime}$ for both carrageenans, indicating a liquid-like state. As gel formation initiates and progresses, both $\mathrm{G}^{\prime}$ and $\mathrm{G}^{\prime \prime}$ increase until the gelpoint $\left(\mathrm{T}_{\text {gel }}\right)$ is reached and $\mathrm{G}^{\prime}$ exceeds $\mathrm{G}^{\prime \prime}$. Figure 3 shows
Fig. 4 Storage modulus, $\mathrm{G}^{\prime}[\mathrm{Pa}]$, measured from 95 to $20^{\circ} \mathrm{C}$ at a rate of $1{ }^{\circ} \mathrm{C} / \mathrm{min}$ for carrageenan with $1 \% \mathrm{KCl}$ from

H. musciformis (extracted with CPHA and $\mathrm{KOH}$ ) and $K$. alvarezii (extracted with CPHA and $\mathrm{KOH}$ )

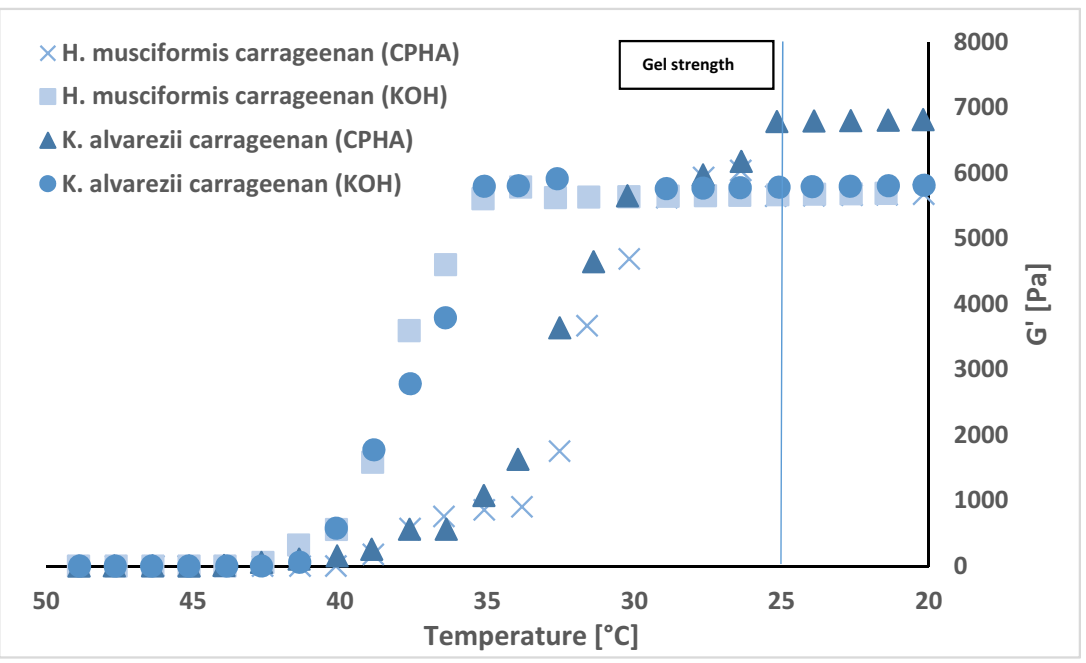


$\tan (\delta)$ as a function of temperature for the H. musciformis carrageenans extracted by either CPHA or $\mathrm{KOH}$ from 80 to $20^{\circ} \mathrm{C}$. $\operatorname{Tan}(\delta)$ is defined as $\mathrm{G}^{\prime \prime} / \mathrm{G}^{\prime}$ and illustrates the liquid and solid behavior of gels, where $\tan (\delta)>1\left(\mathrm{G}^{\prime \prime}>\mathrm{G}^{\prime}\right)$ signifies liquid behavior and $\tan (\delta)<1\left(\mathrm{G}^{\prime \prime}<\mathrm{G}^{\prime}\right)$ implies solid behavior. When $\tan (\delta)=1$, the storage modulus and loss modulus are the same indicating a transition point [16]. The data show that $\tan (\delta)$ is above 1 at high temperatures until transition occurs around $40{ }^{\circ} \mathrm{C}$; below $40{ }^{\circ} \mathrm{C} \tan (\delta)$ decreases steeply to very low values below 1 , and then stabilizes to $\tan (\delta)$ values 0.01-01 from 30 to $20^{\circ} \mathrm{C}$ (Fig. 3). For the carrageenan extracted from $H$. musciformis, $\mathrm{T}_{\text {gel }}$ is estimated to be $36{ }^{\circ} \mathrm{C}$ when extracted with CPHA and $37^{\circ} \mathrm{C}$ when extracted with $\mathrm{KOH}$ (Figs. 2 and 3 and Table 3). Once the gel is formed, $\mathrm{G}^{\prime}$ and $\mathrm{G}^{\prime \prime}$ become constant (Fig. 2). When re-heating the gels, it is observed that $G^{\prime}$ exceeds $G^{\prime \prime}$ until cross-linking of the carrageenan chains is destroyed and both values decrease. When the gels are fully melted $\left(T_{\text {melt }}\right), G^{\prime}$ again has a value lower than $G^{\prime \prime}$. Gelling and melting temperatures for the carrageenans are summarized in Table 3. The gelling profile for the carrageenans extracted from $K$. alvarezii followed the same trend (results not shown) although the $G^{\prime}$ values were a bit higher (Fig. 4).

As also seen in Fig. 4, gel formation for the CPHAextracted carrageenans appears to occur within a longer temperature span than the carrageenans extracted with $\mathrm{KOH}$. This behavior can be explained by the fact that the CPHA solution contains other divalent cations (Table 1) that may bind to the carrageenan chains. Binding of these components might result in a more heterogeneous way of packing the chains during gel formation. The ions do not seem to inhibit gel formation though, as the gel strengths, estimated as $\mathrm{G}^{\prime}$ at $25^{\circ} \mathrm{C}$, do reach and even exceed (K. alvarezii) the ones from the carrageenans extracted by the traditional method (Fig. 4 and Table 3).

\section{Conclusion}

In this work, we evaluated whether CPHA could be used as substitute for $\mathrm{KOH}$ for carrageenan extraction due to the high potassium level in the ash. The results affirmed that similar extraction yields and hydrocolloid compositions were obtained with CPHA as with classical $\mathrm{KOH}$ extraction. Compositional analysis confirmed successful modification of the carrageenans as 3,6-anhydro-galactopyranose, and sulfate contents were the same with CHPA and $\mathrm{KOH}$ extraction. Evaluation of rheological properties indicated excellent gel strengths, estimated as $\mathrm{G}^{\prime}[\mathrm{Pa}]$ at $25{ }^{\circ} \mathrm{C}$, on 5779 and $5929 \mathrm{~Pa}$, respectively. The findings have promising implications for using cocoa pod husk waste for developing extraction of carrageenan seaweed hydrocolloids on circular economy principles.
Funding information This paper is part of the Seaweed Biorefinery Research Project in Ghana (SeaBioGha) supported by Denmark's development cooperation (Grant DANIDA-14-01DTU) Ministry of Foreign Affairs of Denmark. We thank the Water Research Institute (WRI), Council for Scientific Research (CSIR), Accra, Ghana for their technical assistance in collecting the seaweed samples and Kwame Nkrumah University of Science and Technology (KNUST), Kumasi, Ghana for supplying the cocoa pod husk. We also appreciate the donation of cultivated Kappaphycus alvarezii from NhaTrang Institute of Technology Research and Application, Vietnam. Soheila G. Parto, CHEC Research Centre, Dept. of Chemical and Biochemical Engineering, Technical University of Denmark, Søltofts Plads 229, 2800 Kgs. Lyngby Denmark is thanked for assisting with GC-analyses.

\section{Compliance with ethical standards}

Conflict of interest The authors declare that they have no conflict of interest.

\section{References}

1. Ghana Cocoa Board (2014) 45th Annual report and financial statements for the year ended 30. sept. 14. 2014

2. Agyarko K, Asiedu EK (2012) Cocoa pod husk and poultry manure on soil nutrients and cucumber growth. Adv Environ Biol 6:2870 2874

3. Oddoye EOK, Rhule SWA, Agyente-Badu K, Anchirinah V, Ansah FO (2010) Fresh cocoa pod husk as an ingredient in the diets of growing pigs. Sci Res Essays 5:1141-1144

4. Yapo BM, Besson V, Koubala BB, Koffi KL (2013) Adding value to cacao pod husks as a potential antioxidant-dietary fiber source. Am J Food Nutr 1:38-46

5. Afrane G (1992) Leaching of caustic potash from cocoa husk ash. Bioresour Technol 41:101-104

6. Bolton JJ, De Clerck O, John DM (2003) Seaweed diversity patterns in Sub-Saharan Africa In: Decker C, Griffiths CL, Prochaka K, Ras C, Whitfield A (Eds). Proc Mar Biodivers Sub-Saharan Africa Known Unkn p 229-241

7. Ale MT, Barrett K, Addico GND, Rhein-Knudsen N, deGraftJohnson AA, Meyer AS (2016) DNA-based identification and chemical characteristics of Hypnea musciformis from coastal sites in Ghana. Diversity 8:14-27

8. Rhein-Knudsen N, Ale MT, Ajalloueian F, Yu L, Meyer AS (2017) Rheological properties of agar and carrageenan from Ghanaian red seaweeds. Food Hydrocoll 63:50-58

9. Rhein-Knudsen N, Ale MT, Meyer AS (2015) Seaweed hydrocolloid production: an update on enzyme assisted extraction and modification technologies. Mar Drugs 13:3340-3359

10. Sluiter A, Hames B, Hyman D, Payne C, Ruiz R, Scarlata C, Sluiter J, Templeton D, Wolfe J (2008) Determination of total solids in biomass and total dissolved solids in liquid process samples. NREL Technical Report NREL/TP-510-42621 (Issue date 3/31/ 2008), www.nrel.gov/biomass/analytical_procedures.html

11. Sluiter A, Hames B, Ruiz RO, Scarlata C, Sluiter J, Templeton D (2005) Determination of ash in biomass. NREL Technical Report NREL/TP-510-42622 (Issue date 7/17/2005), www.nrel.gov/ biomass/analytical procedures.html

12. Hunter RC, Halverson TL, Anderson RD (1984) Quality assurance for plant tissue analysis by ICP-AES. Commun Soil Sci Plant Anal 15(11):1285-1322

13. Jones B, Vernon WC (1990) Sampling, handling and analysing plant tissue samples. In RL Westerman (Ed) Soil testing and plant analysis $3^{\text {rd }}$ ed SSSA Book Series No 3 
14. Jol CN, Neiss TG, Penninkhof B, Rudolph B, De Ruiter GA (1999) A novel high-performance anion-exchange chromatographic method for the analysis of carra-geenans and agars containing 3,6anhydrogalactose. Anal Biochem 268:213-222

15. Jackson SG, McCandless EL (1978) Simple, rapid, turbidometric determination of inorganic sulfate and/or protein. Anal Biochem 90:802-808

16. Steffe JF (1996) Rheological methods in food processing

17. Simpson BK, Oldham JH, Martin AM (1985) Extraction of potash from cocoa pod husks. Agric Wastes 13:69-73

18. Yaw MI, Asiedu E, Yalley PPK, Senyo DK (2015) Feasibility of using cocoa pod husk ash (CPHA) as a stabilizer in the production of compressed earth bricks. Intl J Eng Res Gen Sci 3:514-524

19. Amoanyi R (2012) The study of alternative chemical stabilization of clays with agricultural waste materials for rural housing. $\mathrm{PhD}$ Thesis, Kvame Nkrumah University of Science and Technology, Kumasi, Ghana

20. van de Velde F, Knutsen SH, Usov AI, Rollema HS, Cerezo AS (2002) ${ }^{1} \mathrm{H}$ and ${ }^{13} \mathrm{C}$ high resolution NMR spectroscopy of carrageenans: application in research and industry. Trends Food Sci Technol 13:73-92

21. De Ruiter GA, Rudolph B (1997) Carrageenan biotechnology. Trends Food Sci Technol 8:389-395
22. Genicot-Joncour S, Poinas A, Richard O, Potin P, Rudolph B, Kloareg B, Helbert W (2009) The cyclization of the 3,6-anhydrogalactose ring of iota-carrageenan is catalyzed by two D-galactose2,6-sulfurylases in the red alga Chondrus crispus. Plant Physiol 151:1609-1616

23. van de Velde F, de Ruiter GA (2002) Carrageenan. In: Steinbüchel A, DeBaets S, van Damme EJ (eds) Biopolymers (vol. 6) polysaccharide II polysaccharides from eukaryotes. Wiley-VCH, Weinheim, pp 245-274

24. Ciancia M, Noseda MD, Matulewicz MC, Cerezo AS (1993) Alkali-modification of carrageenans: mechanism and kinetics in the kappa/iota-, mu/nu- and lambda-series. Carbohydr Polym 20: 95-98

25. Pereira L, Amado AM, Critchley AT, van de Velde F, Ribeiro-Claro PJA (2009) Identification of selected seaweed polysaccharides (phycocolloids) by vibrational spectroscopy (FTIR-ATR and FTRaman). Food Hydrocoll 23:1903-1909

26. Pereira L, Sousa A, Coelho H, Amado AM, Ribeiro-Claro PJA (2003) Use of FTIR, FT-Raman and ${ }^{13}$ C-NMR spectroscopy for identification of some seaweed phycocolloids. Biomol Eng 20: 223-228

27. Matsuhiro B (1996) Vibrational spectroscopy of seaweed galactans. Hydrobiologia 326(327):481-489 